Canadian

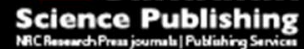

Canadian Journal of Chemistry Revue canadienne de chimie

\title{
Super-size Cp! Tetrabenzo[a,c,g,i]fluorenyl Complexes of Yttrium
}

\begin{tabular}{|r|l|}
\hline Journal: & Canadian Journal of Chemistry \\
\hline Manuscript ID & cjc-2016-0485.R1 \\
\hline Manuscript Type: & Article \\
\hline Date Submitted by the Author: & 31 -Oct-2016 \\
\hline Complete List of Authors: & $\begin{array}{l}\text { Berg, David; University of Victoria, } \\
\text { Sun, Jianlong; University of Victoria, Chemistry } \\
\text { Twamley, Brendan; Idaho, University Research Office }\end{array}$ \\
\hline & yttrium, bulky Cp, fluorenyl, X-ray, insertion \\
\hline
\end{tabular}

\section{SCHOLARONE ${ }^{\text {Th }}$ \\ Manuscripts}


Contribution from:

Department of Chemistry,

University of Victoria, P.O. Box 3065

Victoria, B.C., Canada V8W 3V6

\title{
Super-size Cp! Tetrabenzo[a,c,g,i]fluorenyl Complexes of Yttrium.
}

\author{
Jianlong Sun ${ }^{1}$, David J. Berg*¹ and Brendan Twamley ${ }^{2}$
}

Received:

* Author to whom correspondence should be addressed. Email: djberg@uvic.ca; Phone 250-7217161; Fax 250-721-7147.

${ }^{1}$ Department of Chemistry, University of Victoria, P.O. Box 3065, Victoria, B.C. V8W 3V6

2 University Research Office, 109 Morrill Hall, University of Idaho, Moscow ID 83844-3010 USA; current address: Chemical Sciences, Dublin City University, Glasnevin, Dublin 9, Ireland 


\begin{abstract}
The synthesis of the tetrabenzo[a,c,g,i]fluorenyl (Tbf) yttrium dialkyl complexes, ( Tbf)Y $\left(\mathrm{CH}_{2} \mathrm{SiMe}_{3}\right)_{2}(\mathrm{~L})(\mathrm{L}=\mathrm{THF}, \mathbf{1} ; \mathrm{L}=$ bipy, 2) by direct protonolysis of the tris(alkyl) complex, $\mathrm{Y}\left(\mathrm{CH}_{2} \mathrm{SiMe}_{3}\right)_{3}(\mathrm{THF})_{2}$, are reported. The X-ray crystal structures of $\mathbf{1}$ and $\mathbf{2}$ display the helical twisting typically observed for the Tbf ligand. Dynamic NMR studies on $\mathbf{1}$ show a barrier to Tbf helical inversion (epimerization or 'wagging') of $38.1 \pm 0.5 \mathrm{~kJ} \mathrm{~mol}^{-1}$. Reaction of $\mathbf{1}$ with acidic hydrocarbons such as 1,3-bis(trimethylsilyl)cyclopentadiene or trimethylsilylacetylene results in protonolysis to form the mixed $\mathrm{Cp}$ derivative [(Tbf) $\left.\left\{\mathrm{C}_{5} \mathrm{H}_{3}\left(\mathrm{SiMe}_{3}\right)_{2}\right\} \mathrm{Y}\left(\mathrm{CH}_{2} \mathrm{SiMe}_{3}\right)(\mathrm{THF})\right]$ (3) or $\left[(\mathrm{Tbf}) \mathrm{Y}\left(\mathrm{CCSiMe}_{3}\right)_{2}(\mathrm{THF})\right]_{\mathrm{n}}$ (4), respectively. In the case of 4, a small amount of the trinuclear cluster $(\mathrm{Tbf}) \mathrm{Y}_{3}\left(\mu^{3}-\mathrm{CCSiMe}_{3}\right)_{2}\left(\mu^{2}-\mathrm{CCSiMe}_{3}\right)_{3}\left(\mathrm{CCSiMe}_{3}\right)_{3}(\mathrm{THF})_{2}(\mathbf{5})$ was isolated and characterized by X-ray crystallography. Dialkyl 1 undergoes smooth insertion of trimethylsilyl isocyanate to afford $\left[(\mathrm{Tbf}) \mathrm{Y}\left\{\kappa^{2}-(\mathrm{N}, \mathrm{O})-\mathrm{Me}_{3} \mathrm{SiN}\left(\mathrm{Me}_{3} \mathrm{SiCH}_{2}\right) \mathrm{CO}\right\}_{2}(\mathrm{THF})\right]$ (6) but it does not react with alkenes. Treating 1 with $\left[\mathrm{Ph}_{3} \mathrm{C}\right]^{+}\left[\mathrm{B}\left(\mathrm{C}_{6} \mathrm{~F}_{5}\right)_{4}\right]^{-}$in bromobenzene generates a moderately active ethylene polymerization catalyst $\left(36 \mathrm{~kg} \mathrm{~mol}^{-1} \mathrm{~h}^{-1} \mathrm{bar}^{-1}\right)$.
\end{abstract}

Keywords: yttrium, bulky cyclopentadienyl ligand, fluorenyl, X-ray, alkyl, insertion, organometallic, synthesis 


\section{Dedication}

This contribution is dedicated to Professor Reginal H. Mitchell, an inspirational teacher, gifted researcher and exceptional colleague: I feel exceptionally fortunate to have known you in all these roles. 
Introduction Cyclopentadienyl $(\mathrm{Cp})$ ligands have long been the dominant ancillary ligand in lanthanide organometallic chemistry with those bearing additional alkyl, silyl or phenyl substituents being especially prominent. ${ }^{1}$ Substituted $\mathrm{Cp}$ ligands are widely used because their larger size helps to prevent extensive bridging interactions and ligand redistribution reactions resulting in monomeric or dimeric complexes that are easier to characterize and generally more reactive. However, simply adding bulk to the $\mathrm{Cp}$ ligand, while effective at producing monomeric complexes, can also render the metal center in those same complexes so crowded that reactivity is hindered. This is mainly caused by the fact that the substituents can project into the metallocene wedge in complexes such as $\mathrm{Cp}_{2}{ }_{2} \mathrm{LnR}\left(\mathrm{Cp}^{\prime}=\right.$ substituted $\mathrm{Cp} ; \mathrm{Ln}=\mathrm{Y}$ or a lanthanide), rendering access to the metal center difficult. ${ }^{2}$ To solve this problem, the effective steric bulk of the Cp ligand can be increased by fusing aromatic rings to the $\mathrm{Cp}$ core. This makes dimer formation difficult without blocking access to the metal center by small molecules, effectively creating a pocket of reactivity. This approach has been widely explored using indenyl and fluorenyl ligands in yttrium and lanthanide chemistry but even in these cases, bridging interactions can still occur. ${ }^{3}$ Surprisingly, fusing additional benzene rings to the $\mathrm{Cp}$ core has not been widely explored despite the potential benefits this might offer. ${ }^{4}$ This may be due to the perception that larger fused-aromatic systems would reduce the charge on the $\mathrm{Cp}$ core by delocalization, resulting in weaker binding to the lanthanide center. While there are some examples of ligand loss in larger $\pi$-systems, calculations have shown that the charge on the $\mathrm{Cp}$ core carbons is not substantially diminished by fusion of additional benzene rings to a fluorenyl anion. ${ }^{4 a, 5}$

We have been exploring yttrium and lanthanide chemistry of large aromatic anions including the phenathrene-fused $\mathrm{Cp}$ derivatives, $\mathrm{PC} \mathrm{p}^{\mathrm{R}}$, and the large non-Cp aromatic phenalenide anion, $\mathrm{Pn}^{\mathrm{R}}$ (Fig. 1). ${ }^{6,7}$ Only the PCp* ligand (Fig. 1b) always forms monomeric, mono(ligand) complexes but 
ligand loss is only a feature of the chemistry of the $\mathrm{Pn}^{\mathrm{R}}$ supported complexes. ${ }^{7}$ These observations suggested that the larger tetrabenzo[a,c,g,i]fluorenyl anion (Tbf, Fig. 2) might be an ideal ligand candidate for yttrium chemistry. This ligand system has been used successfully in titanium chemistry and recently it has been shown that ammonium salts of the Tbf anion are stable in water. ${ }^{8,9}$ In this contribution we show that this is indeed the case: the Tbf ligand system allows formation of highly stable complexes of the type, $(\mathrm{Tbf}) \mathrm{Y}\left(\mathrm{CH}_{2} \mathrm{SiMe}_{3}\right)_{2}(\mathrm{~L})(\mathrm{L}=\mathrm{THF}$, bipy) that do not undergo redistribution. The synthesis, solid state and solution structure, and reactivity of this complex are discussed.

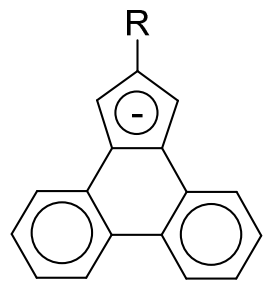

(a) $P C p^{R}(R=H, M e, P h)$

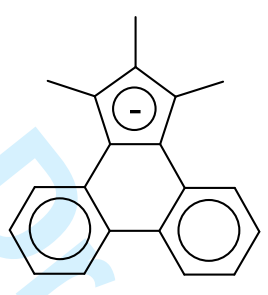

(b) $P C p^{*}$

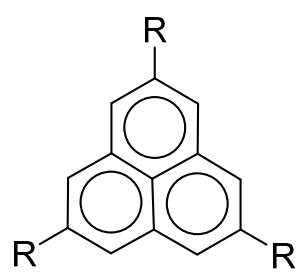

(c) $\mathrm{Pn}^{\mathrm{R}}(\mathrm{R}=\mathrm{H}, \mathrm{t}-\mathrm{Bu})$

Fig. 1 Large aromatic anions

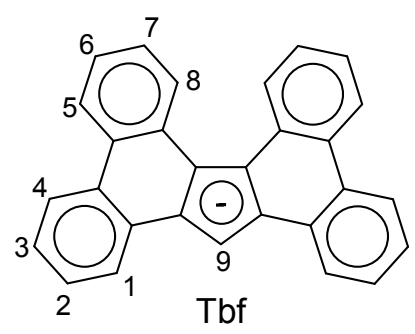

Fig. 2 The tetrabenzo[a,c,g,i]fluorenyl anion including numbering for NMR assignments

\section{Experimental}

General Procedures. All manipulations were carried out under a nitrogen atmosphere using Schlenk or glovebox (Braun MB150-GII) techniques. Tetrahydrofuran (THF) and diethyl ether 
were dried by distillation from sodium benzophenone ketyl under nitrogen immediately prior to use. Hexane and toluene were dried and degassed using a Braun solvent purification system. $\left[\mathrm{Y}\left(\mathrm{CH}_{2} \mathrm{SiMe}_{3}\right)_{3}(\mathrm{THF})_{2}\right]$ and the Tbf-H parent hydrocarbon were prepared according to literature procedures. $^{10,11}$ 2,2'-Bipyridine, trimethylsilylisocyanate, trimethylsilylacetylene and trityl tetrakis(pentafluorophenyl)borate were purchased commercially and purified by recrystallization or distillation prior to use. All ${ }^{1} \mathrm{H}$ and ${ }^{13} \mathrm{C}$ NMR spectra were recorded on Bruker 300,360 or 500 $\mathrm{MHz}$ spectrometers referenced to residual solvent resonances. ${ }^{19} \mathrm{~F},{ }^{11} \mathrm{~B}$, and ${ }^{29} \mathrm{Si}$ NMR spectra were recorded on a Bruker AMX500 spectrometer referenced to external standards $\left(\mathrm{CCl}_{3} \mathrm{~F}, \mathrm{BF}_{3}\left(\mathrm{OEt}_{2}\right)\right.$ and $\mathrm{SiMe}_{4}$ set to $\left.0 \mathrm{ppm}\right)$. All deuterated solvents were dried over activated $4 \AA$ molecular sieves and spectra were recorded using $5 \mathrm{~mm}$ tubes fitted with a Teflon valve (Brunfeldt). Melting points were recorded using a Büchi melting point apparatus and are not corrected.

[(Tbf)Y(CH $\left.\left.\mathbf{C H}_{2} \mathrm{SiMe}_{3}\right)_{2}(\mathbf{T H F})\right]$ (1) A solution of Tbf-H $(0.123 \mathrm{~g}, 0.34 \mathrm{mmol})$ in $5 \mathrm{~mL}$ toluene was added to a solution of $\left[\mathrm{Y}\left(\mathrm{CH}_{2} \mathrm{SiMe}_{3}\right)_{3}(\mathrm{THF})_{2}\right](0.170 \mathrm{~g}, 0.34 \mathrm{mmol})$ in $5 \mathrm{~mL}$ toluene at $0{ }^{\circ} \mathrm{C}$. The reaction mixture was allowed to warm to room temperature overnight with rapid stirring followed by removal of solvent under vacuum. The Schlenk flask was transferred to the glovebox, $40 \mathrm{~mL}$ hexanes was added and the resulting solution was filtered through Celite. Evaporation of the filtrate under reduced pressure gave crude $\mathbf{1}$ as a yellow powder. Recrystallization of this solid from hexanes produced pale yellow crystals of 1 at $-35{ }^{\circ} \mathrm{C}$. Yield: $0.188 \mathrm{~g}(88 \%)$. Mp $134{ }^{\circ} \mathrm{C}(\mathrm{dec}) .{ }^{1} \mathrm{H}$ $\operatorname{NMR}\left(500 \mathrm{MHz}, \mathrm{C}_{6} \mathrm{D}_{6}\right): \delta 9.03\left(\mathrm{dd},{ }^{3} J_{\mathrm{HH}}=8.0 \mathrm{~Hz},{ }^{4} J_{\mathrm{HH}}=1.2 \mathrm{~Hz}, 2 \mathrm{H}, 8-\operatorname{arylH}\right), 8.40\left(\mathrm{dd},{ }^{3} J_{\mathrm{HH}}=\right.$ $\left.8.0 \mathrm{~Hz},{ }^{4} J_{\mathrm{HH}}=1.2 \mathrm{~Hz}, 2 \mathrm{H}, 1-\operatorname{arylH}\right), 8.37(\mathrm{~m}, 4 \mathrm{H}, 4,5-\operatorname{arylH}), 8.00(\mathrm{~s}, 1 \mathrm{H}, 9-C p H), 7.48(\mathrm{~m}, 2 \mathrm{H}, 2-$ arylH), 7.38-7.34 (m, 4H, 3,6-arylH), 7.30 (m, 2H, 7-arylH), 2.54 (br m, 4H, $\alpha-\mathrm{CH}_{2}$ THF), 0.59 (br $\left.\mathrm{m}, 4 \mathrm{H}, \beta-\mathrm{CH}_{2} \mathrm{THF}\right), 0.02(\mathrm{~s}, 18 \mathrm{H}, \mathrm{SiMe}),-0.98\left(\mathrm{~d},{ }^{2} \mathrm{~J}_{\mathrm{YH}}=3.1 \mathrm{~Hz}, 4 \mathrm{H}, \mathrm{Y}-\mathrm{CH}_{2}\right) ;{ }^{13} \mathrm{C}\left\{{ }^{1} \mathrm{H}\right\} \mathrm{NMR}$ 
$\left(125 \mathrm{MHz}, \mathrm{C}_{6} \mathrm{D}_{6}\right): \delta 131.11,130.69,130.06,129.16,128.11,127.26,126.88,126.52,125.90$, 125.64, 125.11, 125.07, 124.21, 115.53 (arylC), $92.41(\mathrm{CpCH}), 70.40,24.66(T H F), 37.92\left(\mathrm{~d},{ }^{1} J_{\mathrm{YC}}\right.$ $\left.=45 \mathrm{~Hz}, \mathrm{Y}-\mathrm{CH}_{2}\right), 4.34\left(\mathrm{Si}_{\mathrm{Me}}\right)$. Anal. Calcd. for $\mathrm{C}_{41} \mathrm{H}_{47} \mathrm{OSi}_{2} \mathrm{Y}: \mathrm{C} 70.26, \mathrm{H} 6.76$; found: C 70.31, $\mathrm{H}$ 6.67.

\section{$\left[(\mathrm{Tbf}) \mathrm{Y}\left(\mathrm{CH}_{2} \mathrm{SiMe}_{3}\right)_{2}(\mathrm{bipy})\right]$ (2)}

Addition of $0.030 \mathrm{~g} 2.2$ '-bipyridine $(0.2 \mathrm{mmol})$ to $0.14 \mathrm{~g} 1(0.2 \mathrm{mmol})$ in $10 \mathrm{~mL}$ toluene produced a dark red solution. Removal of the solvent under reduced pressure gave $\mathbf{2}$ as a red powder. Recrystallization of the powder from a hot mixture of toluene and hexanes afforded deep red crystals of pure 2. Yield: $0.152 \mathrm{~g}(97 \%) . \mathrm{Mp} .220^{\circ} \mathrm{C}$ (dec.). ${ }^{1} \mathrm{H}$ NMR $\left(500 \mathrm{MHz}, \mathrm{C}_{6} \mathrm{D}_{6}\right): \delta 8.60\left(\mathrm{~d},{ }^{3} \mathrm{~J}_{\mathrm{HH}}=8.0 \mathrm{~Hz}, 2 \mathrm{H}, 8-\operatorname{arylH}\right), 8.28\left(\mathrm{~d},{ }^{3} \mathrm{~J}_{\mathrm{HH}}=8.0 \mathrm{~Hz}, 2 \mathrm{H}, 1-\right.$ $\operatorname{arylH}), 8.28(\mathrm{~s}, 1 \mathrm{H}, 9-C p H), 8.18\left(\mathrm{~d},{ }^{3} J_{\mathrm{HH}}=8.4 \mathrm{~Hz}, 4 \mathrm{H}, 4,5-\operatorname{arylH}\right), 7.63\left(\mathrm{~d},{ }^{3} J_{\mathrm{HH}}=5.2 \mathrm{~Hz}, 2 \mathrm{H}, 6-\right.$ bipyH), $7.55\left(\mathrm{t},{ }^{3} J_{\mathrm{HH}}=7.4 \mathrm{~Hz}, 2 \mathrm{H}, 7-\operatorname{arylH}\right), 7.37(\mathrm{~m}, 2 \mathrm{H}, 2-\operatorname{arylH}), 7.09\left(\mathrm{t},{ }^{3} J_{\mathrm{HH}}=7.8 \mathrm{~Hz}, 2 \mathrm{H}, 6-\right.$ $\operatorname{arylH}), 6.89\left(\mathrm{t},{ }^{3} J_{\mathrm{HH}}=7.5 \mathrm{~Hz}, 2 \mathrm{H}, 3-\operatorname{arylH}\right), 6.57\left(\mathrm{dt},{ }^{3} J_{\mathrm{HH}}=7.8 \mathrm{~Hz},{ }^{4} J_{\mathrm{HH}}=1.5 \mathrm{~Hz}, 2 \mathrm{H}, 4-\right.$ bipyH), $6.36\left(\mathrm{~d}, 2 \mathrm{H},{ }^{3} J_{\mathrm{HH}}=7.8 \mathrm{~Hz}, 3-\right.$ bipyH), $6.11\left(\mathrm{t}, 2 \mathrm{H},{ }^{3} J_{\mathrm{HH}}=6.3 \mathrm{~Hz}, 5-\right.$ bipyH), $0.06(\mathrm{~s}, 18 \mathrm{H}, \mathrm{SiMe})$, $0.82\left(\mathrm{dd},{ }^{2} J_{\mathrm{YH}}=3.0 \mathrm{~Hz},{ }^{2} J_{\mathrm{HH}}=11.5 \mathrm{~Hz}, 2 \mathrm{H}, \mathrm{YCH}\right),-0.88\left(\mathrm{dd},{ }^{2} J_{\mathrm{YH}}=3.0 \mathrm{~Hz},{ }^{2} J_{\mathrm{HH}}=11.0 \mathrm{~Hz}, 2 \mathrm{H}\right.$, $\left.\mathrm{YCH}_{2}\right)$. The ${ }^{13} \mathrm{C}\left\{{ }^{1} \mathrm{H}\right\}$ NMR was not obtained due to the low solubility of this compound. Anal. Calcd. for $\mathrm{C}_{47} \mathrm{H}_{47} \mathrm{~N}_{2} \mathrm{Si}_{2} \mathrm{Y}$ : C 71.92, H 6.04, N 3.57; found: C 70.55, H 6.00, N 3.71.

$\left[\left(\mathrm{Tbf}\left\{\left(\mathrm{C}_{5} \mathrm{H}_{3}\left(\mathrm{SiMe}_{3}\right)_{2}\right\} \mathbf{Y}\left(\mathrm{CH}_{2} \mathrm{SiMe}_{3}\right)(\mathrm{THF})\right]\right.\right.$ (3) Addition of a solution of $\mathrm{H}\left[\mathrm{C}_{5} \mathrm{H}_{3}\left(\mathrm{SiMe}_{3}\right)_{2}\right](0.120 \mathrm{~g}, 0.57 \mathrm{mmol})$ in $20 \mathrm{~mL}$ toluene was added to a solution of $\mathbf{1}(0.390 \mathrm{~g}$, $0.556 \mathrm{mmol}$ ) in $10 \mathrm{~mL}$ toluene. The reaction mixture was allowed to stir at room temperature overnight followed by removal of solvent under vacuum. The residue was washed repeatedly with hexane and recrystallized from hot toluene to yield the mixed ligand complex $\mathbf{3}$ as a pale yellow powder (0.28 g, 61\%). Mp $158^{\circ} \mathrm{C}(\mathrm{dec}) .{ }^{1} \mathrm{H}$ NMR (500 MHz, $\left.\mathrm{C}_{6} \mathrm{D}_{6}\right): \delta 9.19(\mathrm{~d}, 1 \mathrm{H}, 8$-arylH), 9.13 (d, 1H, 8'-aryl H), $8.41(\mathrm{~m}, 2 \mathrm{H}$, overlapping 1 - and l'-arylH), $8.34(\sim \mathrm{d}, 2 \mathrm{H}, \operatorname{arylH}), 8.32(\mathrm{~d}, 1 \mathrm{H}$, 
arylH), $8.23(\mathrm{~d}, 1 \mathrm{H}$, aryl H), $7.77(\mathrm{~s}, 1 \mathrm{H}, 9-\mathrm{CpH}), 7.51(\mathrm{t}, 1 \mathrm{H}, \operatorname{arylH}), 7.44(\mathrm{~m}, 2 \mathrm{H}, \operatorname{arylH}), 7.29-$ $7.39(\mathrm{~m}, 5 \mathrm{H}, \operatorname{arylH}), 6.19\left(\mathrm{~m}, 1 \mathrm{H}, J=2.5 \mathrm{~Hz}, \mathrm{C}_{5} H_{3}\left(\mathrm{SiMe}_{3}\right)_{2}\right), 5.70(\mathrm{~m}, 1 \mathrm{H}, J=1.5 \mathrm{~Hz}$, $\left.\mathrm{C}_{5} H_{3}\left(\mathrm{SiMe}_{3}\right)_{2}\right), 4.61\left(\mathrm{~m}, 1 \mathrm{H}, J=2.5 \mathrm{~Hz}, \mathrm{C}_{5} H_{3}\left(\mathrm{SiMe}_{3}\right)_{2}\right), 2.25$ (m, 2H, $\left.\alpha-\mathrm{CH}_{2} \mathrm{THF}\right), 2.16$ (m, 2H, $\alpha$-CH $H_{2}$ THF), 0.50 (br m, 4H, $\beta$-CH $H_{2}$ THF), 0.41 (s, 6H, SiMe $e_{3}$ ), 0.35 (s, 3H, SiMe $e_{3}$ ), 0.32 (s, 3H, $\mathrm{SiMe}$ ), 0.07 (s, 9H, $\left.\mathrm{CH}_{2} \mathrm{Si}_{2} e_{3}\right), 0.03$ (s, 3H, SiMe $),-0.02$ (s, 3H, SiMe $),-1.82\left(\mathrm{dd}, 1 \mathrm{H},{ }^{2} J_{\mathrm{YH}}=3.7\right.$ $\left.\mathrm{Hz},{ }^{2} J_{H H}=10 \mathrm{HZ}, \mathrm{Y}-\mathrm{CH}_{2} \mathrm{SiMe}_{3}\right),-2.16\left(\mathrm{dd}, 1 \mathrm{H},{ }^{2} J_{\mathrm{YH}}=3.7 \mathrm{~Hz},{ }^{2} J_{\mathrm{HH}}=10 \mathrm{HZ}, \mathrm{Y}_{-}-\mathrm{CH}_{2} \mathrm{SiMe}_{3}\right)$; ${ }^{13} \mathrm{C}\left\{{ }^{1} \mathrm{H}\right\}$ NMR $\left(125 \mathrm{MHz}, \mathrm{C}_{6} \mathrm{D}_{6}\right): \delta 131.87,131.73,130.50,130.39,130.08,129.99,129.90$, $129.80,129.66,128.89,127.86,127.76,127.70,126.62,126.55,126.35,126.28,126.22,125.57$, $125.52,125.28,125.14,124.94,124.75,124.56,124.14,121.89,121.87,121.70,121.40,121.06$ 116.43, $114.57(\operatorname{aryl} C), 91.65,\left(\mathrm{P}^{2} \mathrm{CpCH}\right), 70.97(\alpha-C \mathrm{THF}), 25.82\left(\mathrm{~d},{ }^{1} J_{Y C}=40 \mathrm{~Hz}, \mathrm{Y}-\mathrm{CH}_{2}\right), 24.48$ ( $\beta$-C THF), 2.48, 1.58, 0.81, 0.36, $-0.10,-0.30\left(\mathrm{C}_{5} \mathrm{H}_{3}\left(\mathrm{SiMe}_{3}\right)_{2}\right), 1.29\left(\mathrm{CH}_{2} \mathrm{SiMe}_{3}\right)$. Anal. Calcd. for $\mathrm{C}_{48} \mathrm{H}_{57} \mathrm{OSi}_{3} \mathrm{Y}: \mathrm{C} 70.04, \mathrm{H} 6.98$; found: C 69.35, H 6.92.

$\left.\left[(\mathbf{T b f}) \mathbf{Y}(\mathbf{C C S i M e})_{2}\right)_{2}(\mathbf{T H F})\right]_{\mathbf{n}}$ (4) A solution of trimethysilylacetylene $(0.030 \mathrm{~g}, 0.31 \mathrm{mmol})$ in $1 \mathrm{~mL}$ hexane was added dropwise to a vigorously stirred solution of $\mathbf{1}(0.043 \mathrm{~g}, 0.061 \mathrm{mmol})$ in 5 $\mathrm{mL}$ hexane. The mixture immediately became cloudy and after stirring overnight, the solution was filtered through Celite and the solvent removed under reduced pressure to afford a pale yellow powder, 4. Yield: $0.030 \mathrm{~g}(68 \%)$. Mp $125-8{ }^{\circ} \mathrm{C}(\mathrm{dec}) .{ }^{1} \mathrm{H}$ NMR $\left(500 \mathrm{MHz}, \mathrm{C}_{6} \mathrm{D}_{6}\right): \delta 9.86\left(\mathrm{~d},{ }^{3} J_{\mathrm{HH}}=\right.$ $8.3 \mathrm{~Hz}, 2 \mathrm{H}, 8-\operatorname{arylH}), 8.72\left(\mathrm{dd},{ }^{3} J_{\mathrm{HH}}=7.9 \mathrm{~Hz}, 2 \mathrm{H}, 1\right.$-arylH), $8.59(\mathrm{~s}, 1 \mathrm{H}, 9-\mathrm{CpH}), 8.46\left(\mathrm{~d}, 2 \mathrm{H},{ }^{3} J_{\mathrm{HH}}\right.$ $=7.6 \mathrm{~Hz}, 5-\operatorname{aryl} H), 8.41\left(\mathrm{~d},{ }^{3} J_{\mathrm{HH}}=8.0 \mathrm{~Hz}, 2 \mathrm{H}, 4-\operatorname{aryl} H\right), 7.58(\mathrm{~m}, 2 \mathrm{H}, 7-\operatorname{arylH}), 7.45(\mathrm{~m}, 2 \mathrm{H}, 2-$ arylh), 7.40 (m, 2H, 6-arylH), 7.33 (m, 2H, 3-arylH), 3.55 (br m, 4H, $\alpha$-CH $\left.\mathrm{CH}_{2} \mathrm{THF}\right), 1.46$ (br m, 4H, $\beta$ - $\mathrm{CH}_{2}$ THF), 0.21 (s, 18H, SiMe $) ;{ }^{13} \mathrm{C}\left\{{ }^{1} \mathrm{H}\right\} \mathrm{NMR}\left(125.8 \mathrm{MHz}, \mathrm{C}_{6} \mathrm{D}_{6}\right): \delta 172.46\left(\mathrm{~d},{ }^{1} J_{\mathrm{YC}}=47.8 \mathrm{~Hz}\right.$, Y-CCSiMe 3 ), 132.92, 131.16, 130.62, 129.88, 129.09, 127.03, 125.93, 125.86, 125.75, 125.54 , 124.76, 123.71, 123.53, 116.87 (arylC), $111.95\left(\mathrm{~d},{ }^{2} J_{\mathrm{YC}}=8.8 \mathrm{~Hz}, \mathrm{Y}-\mathrm{CCSiMe}\right), 98.99(9-\mathrm{CpCH})$, 
$1.69\left(\mathrm{Si}_{3}\right)$. THF resonances in this complex overlap with the residual solvent resonances of $\mathrm{d}_{8}$ THF at 68 and 25 ppm. Anal. Calcd. for $\mathrm{C}_{43} \mathrm{H}_{43} \mathrm{OSi}_{2} \mathrm{Y}$ : C 71.64, H 6.01; found: C 71.18, H 5.89. Recrystallization of $\mathbf{3}$ from hot toluene resulted in formation of a small amount of well-formed crystals that proved, by X-ray crystallography (vide infra) to be the alkynide cluster compound, $(\mathrm{Tbf}) \mathrm{Y}_{3}\left(\mu^{3}-\mathrm{CCSiMe}_{3}\right)\left(\mu^{2}-\mathrm{CCSiMe}_{3}\right)_{3}\left(\mathrm{CCSiMe}_{3}\right)_{4}(\mathrm{THF})_{2}, \mathbf{5}$.

\section{[(Tbf)Y $\left\{\boldsymbol{\kappa}^{2}-(\mathbf{N}, \mathbf{O})-\mathrm{Me}_{3} \mathrm{SiN}\left(\mathrm{Me}_{3} \mathrm{SiCH}_{2}\right) \mathbf{C O}\right\}_{\mathbf{2}}$ (THF)] (6) $\mathrm{Me}_{3} \mathrm{SiNCO}(0.060 \mathrm{~g}, 0.50 \mathrm{mmol})$ was} added to $0.070 \mathrm{~g}$ of $\mathbf{1}(0.10 \mathrm{mmol})$ in $10 \mathrm{~mL}$ toluene and the solution was allowed to stir at room temperature overnight. Evaporation of the solvent under vacuum afforded a pale yellow solid. Yield: $0.090 \mathrm{~g}(96 \%) .{ }^{1} \mathrm{H}$ NMR $\left(300 \mathrm{MHz}, \mathrm{C}_{6} \mathrm{D}_{6}\right): \delta 9.22\left(\mathrm{~d},{ }^{3} \mathrm{~J}_{\mathrm{HH}}=7.9 \mathrm{~Hz}, 2 \mathrm{H}, 8\right.$-arylH), 8.42-8.47 (m, 6H, 1,4,5,-arylH), $7.90(\mathrm{~s}, 1 \mathrm{H}, 9-C p H), 7.35-7.52(\mathrm{~m}, 8 \mathrm{H}, 2,3,6,7-\operatorname{arylH}), 2.99$ (br m, 4H, $\alpha-$ $\mathrm{CH}_{2} \mathrm{THF}$ ), 1.37 (s, 4H, $\mathrm{CH}_{2} \mathrm{SiMe}_{3}$ ), 1.01 (br m, 4H, $\left.\beta-\mathrm{CH}_{2} \mathrm{THF}\right), 0.02$ (s, 18H, CH $\mathrm{SiMe}_{3}$ ), -0.22 (s, 18H, NSiMe $) ;{ }^{13} \mathrm{C}\left\{{ }^{1} \mathrm{H}\right\}$ NMR (75 MHz, C $\left.6 \mathrm{D}_{6}\right): \delta 188.78$ (NCO), 130.09, 128.70, 128.38, 127.57, 127.24, 126.11, 125.28, 125.07, 124.58, 124.25, 115.60 (arylC), 94.89 (CpCH), 69.53, 25.51 (THF), $30.89\left(\mathrm{CH}_{2} \mathrm{SiMe}_{3}\right), \quad 1.53\left(\mathrm{CH}_{2} \mathrm{SiMe}\right)_{3},-0.22 \quad(\mathrm{NSiMe})$. Anal. Calcd. for $\mathrm{C}_{49} \mathrm{H}_{65} \mathrm{~N}_{2} \mathrm{O}_{3} \mathrm{Si}_{4} \mathrm{Y}:$ C 63.19, H 7.03, N 3.01; found: C 63.33, H 7.08, N 2.78.

\section{Alkyl abstraction product, $7 \quad$ A solution of $\left[\mathrm{Ph}_{3} \mathrm{C}\right]^{+}\left[\mathrm{B}\left(\mathrm{C}_{6} \mathrm{~F}_{5}\right)_{4}\right]^{-}(0.030 \mathrm{~g}, 0.033 \mathrm{mmol})$ in 1} $\mathrm{mL}$ toluene was added to $1(0.023 \mathrm{~g}, 0.033 \mathrm{mmol})$ in $3 \mathrm{~mL}$ toluene with vigorous stirring. The solution turned deep red immediately but the colour faded to pale peach within 30 minutes indicating complete formation of the cationic complex. The solvent was removed from the reaction mixture under reduced pressure and the oily solid was characterized by NMR. The ${ }^{1} \mathrm{H}$ NMR of this material was quite broad and consisted of many overlapping resonances and we were unable to remove these impurities by washing or recrystallization. ${ }^{19} \mathrm{~F}$ NMR $\left(470.4 \mathrm{MHz}, \mathrm{C}_{6} \mathrm{D}_{5} \mathrm{Br}\right): \delta-131.7$ (br s, ortho-aryl F), -161.8 (t, ${ }^{3} J_{\mathrm{FF}}=30 \mathrm{~Hz}$, para-aryl $\left.F\right),-165.7\left(\mathrm{v}\right.$ br t, ${ }^{3} J_{\mathrm{FF}}=30 \mathrm{~Hz}$, meta-aryl $\left.F\right)$; 
${ }^{11} \mathrm{~B}$ NMR (160.4 MHz, $\left.\mathrm{C}_{6} \mathrm{D}_{5} \mathrm{Br}\right): \delta-16.2 ;{ }^{29} \mathrm{Si}$ NMR $\left(99.3 \mathrm{MHz}, \mathrm{C}_{6} \mathrm{D}_{5} \mathrm{Br}\right): \delta-0.09,-1.33$. On standing for several days, a few colourless crystals deposited in the NMR tube that proved by X-ray crystallography to be the $[\mathrm{Tbf}]_{2}$ dimer $\mathbf{8}$ (vide infra).

Ethylene polymerization with 7. A solution of the alkyl abstraction product 7, generated as described above in a Kontes flask, was frozen in liquid nitrogen and the headspace of the flask was evacuated for several minutes followed by introduction of ethylene gas ( 1 bar). The flask was removed from liquid nitrogen and the flask sealed and placed in a water bath at $20{ }^{\circ} \mathrm{C}$. The reaction mixture turned yellow and a white precipitate formed. After 30 minutes, methanol was introduced resulting in a colour change to colourless. The precipitate was washed with $1 \mathrm{M} \mathrm{HCl}$ and methanol before drying to constant weight at $60{ }^{\circ} \mathrm{C}$ under reduced pressure. The activity of 7 was calculated to be $36 \mathrm{~kg}$ polyethene $\mathrm{mol}^{-1} \mathrm{~h}^{-1}$ bar $^{-1}$ (assuming the active species was $\left.\left[(\mathrm{Tbf}) \mathrm{Y}\left(\mathrm{CH}_{2} \mathrm{SiMe}_{3}\right)\right]^{+}\left[\mathrm{B}\left(\mathrm{C}_{6} \mathrm{~F}_{5}\right)_{4}\right]^{-}\right)$.

\section{X-ray crystallographic studies. Crystals of the compound to be examined were} removed from a sealed glass ampoule under a nitrogen atmosphere and covered with a layer of Paratone oil. A suitable crystal was selected, attached to a MiTeGen fiber and placed in the lowtemperature nitrogen stream. ${ }^{12}$ Data for $\mathbf{1}, \mathbf{2}, \mathbf{5}$ and $\mathbf{8}$ were collected at low temperature $(87(2) \mathrm{K}$ for 1, 5 and 8; 185(2)K for 2) using a Bruker/Siemens SMART APEX instrument (Mo K $\alpha$ radiation, $\lambda$ $=0.71073 \AA$ ) equipped with a Cryocool NeverIce low temperature device. Data were measured using omega scans of $0.3^{\circ}$ per frame for $10(\mathbf{1}), 20(\mathbf{2}), 30(\mathbf{5})$ or 60 (8) seconds, and a full sphere of data was collected. A total of $2450(\mathbf{1}, \mathbf{5}, \mathbf{8})$ or 2400 (2) frames were collected with a final resolution of $0.77(\mathbf{1}), 0.83(\mathbf{2}$ and $\mathbf{8})$ or $0.93(\mathbf{5}) \AA$. The first 50 frames were recollected at the end of data collection to monitor for decay. Cell parameters were retrieved using SMART software and refined using SAINTPlus ${ }^{13}$ on all observed reflections. Data reduction and correction for Lp and 
decay were performed using the SAINTPlus software. Absorption corrections were applied using SADABS. ${ }^{14}$ The structures were solved by direct methods and refined by least squares method on $\mathrm{F}^{2}$ using the SHELXTL program package. ${ }^{15}$ The structures were solved in the space group $\mathrm{P} 2{ }_{1} / \mathrm{n}$ (No. 14) for $\mathbf{1}, \mathbf{2}$ and $\mathbf{8}$ and in $\mathrm{P} 2 / 1$ c (No. 14) for $\mathbf{5}$ by analysis of systematic absences. All atoms were refined anisotropically for $\mathbf{1}, \mathbf{2}$ and $\mathbf{8}$. For 5, all non-hydrogen atoms were refined anisotropically except for the atoms of both THF molecules, C42 and C75 and the partially occupied ligand ( $\mathrm{HCCSiMe}_{3}$ ). The disordered THF groups in $\mathbf{5}$ were refined at $65 \%$ for the major moiety. No decomposition was observed during data collection. A summary of the basic crystallographic data is given in Table 1.

\section{[Table 1]}

\section{Results and Discussion}

Synthesis and Characterization. One equivalent of the parent ligand, Tbf- $\mathrm{H}$, reacted smoothly with one equivalent of $\mathrm{Y}\left(\mathrm{CH}_{2} \mathrm{SiMe}_{3}\right)_{3}(\mathrm{THF})_{2}$ in toluene to produce the mono ligand complex (Tbf) $\mathrm{Y}\left(\mathrm{CH}_{2} \mathrm{SiMe}_{3}\right)_{2}(\mathrm{THF})$, 1, in good yield (Scheme 1). Attempts to generate the bis ligand complex using two equivalents of Tbf-H failed even under forcing conditions (heating at 80 ${ }^{\circ} \mathrm{C}$ for extended times), presumably indicating that the mono $\mathrm{Tbf}$ complex is the steric limit with yttrium as the metal. Adding 1 equivalent of 2,2'-bipyridine results in similar formation of the bipy adduct, ( $\mathrm{Tbf}) \mathrm{Y}\left(\mathrm{CH}_{2} \mathrm{SiMe}_{3}\right)_{2}$ (bipy), 2, in excellent yield. Complex $\mathbf{2}$ is considerably less soluble in toluene than $\mathbf{1 .}$

\section{Scheme 1}




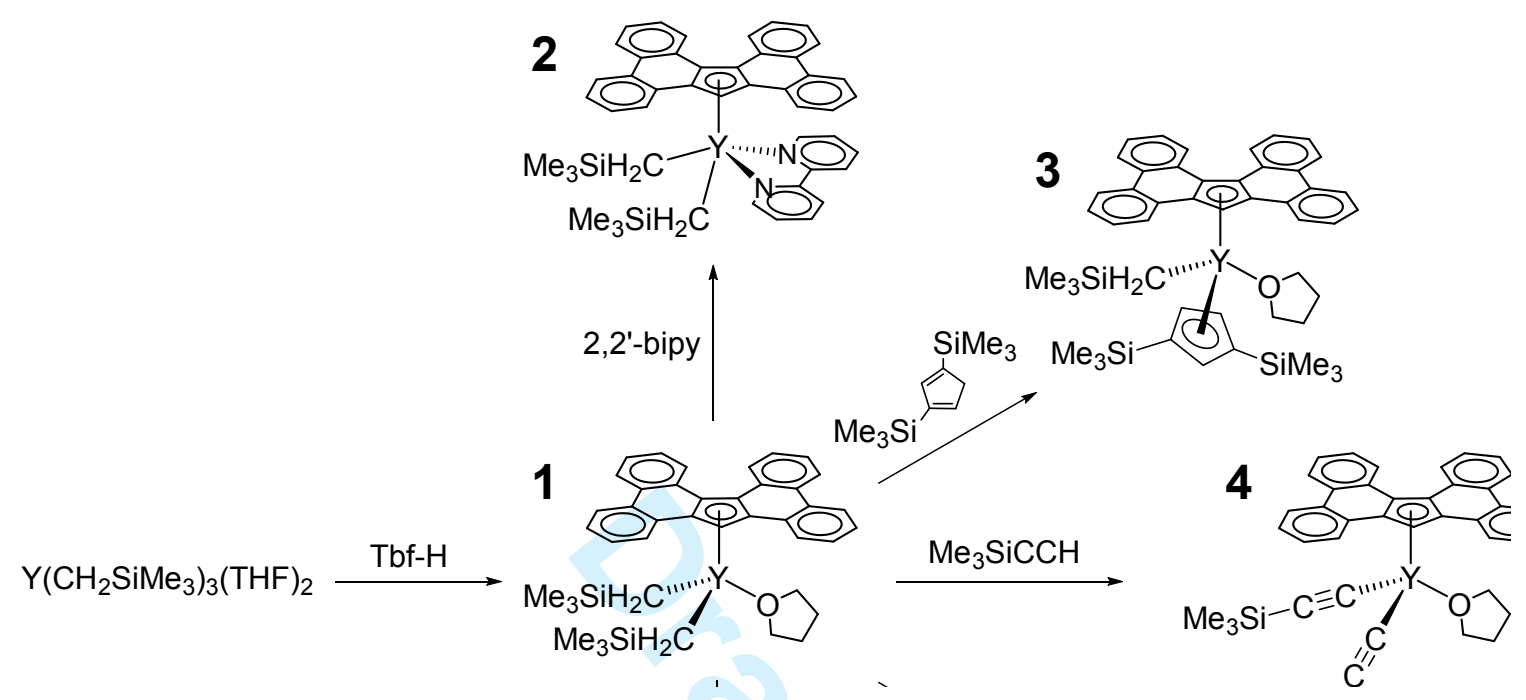

Crystals of 1, grown from hot toluene solution, were examined by X-ray crystallography. This complex was found to adopt a three-legged piano stool geometry in the solid state (Fig. 3, Table 2). The Y-C bond distances to the $\mathrm{CH}_{2} \mathrm{SiMe}_{3}$ groups (2.353(3), 2.360(3) $\AA$ ) are slightly shorter than those previously reported for pseudo-tetrahedral $\mathrm{Cp}^{\prime} \mathrm{Y}\left(\mathrm{CH}_{2} \mathrm{SiMe}_{3}\right)_{2}(\mathrm{THF})$ complexes (median: 2.381 $\AA$; range: $2.370-2.390 \AA) .{ }^{6 b, 16}$ There is slight Tbf ring slippage towards $\eta^{3}\left(\Delta_{\text {slip }}=\right.$ average of 2 longest Y-C distances - average of 3 shortest Y-C distances $=0.08 \AA$ ) observable but the complex is best characterized as possessing an $\eta^{5}$-Tbf ligand. In contrast, the bipy complex 2 adopts a distorted square pyramidal geometry with the Tbf ligand in the axial position (Fig. 4, Table 2). As expected, the Y-C bond distances to the $\mathrm{CH}_{2} \mathrm{SiMe}_{3}$ group (2.396(2), 2.423(2) $\AA$ ) are longer than 
those in $\mathbf{1}$ due to the higher coordination number but they are again somewhat shorter than those in the only directly comparable compound, $\mathrm{Cp} * \mathrm{Lu}\left(\mathrm{CH}_{2} \mathrm{SiMe}_{3}\right)_{2}(\mathrm{py})_{2}$, after correction for the difference in metal ionic radii (corrected: $2.444(9), 2.452(11) \AA) .{ }^{17}$ There is slightly more $\eta^{3}$ ring slippage in $\mathbf{2}$ than in $\mathbf{1}\left(\Delta_{\text {slip }}=0.10 \AA\right)$, but given the fact that the Y-C bonds are relatively short compared to similar compounds, this does not appear to be sterically driven.

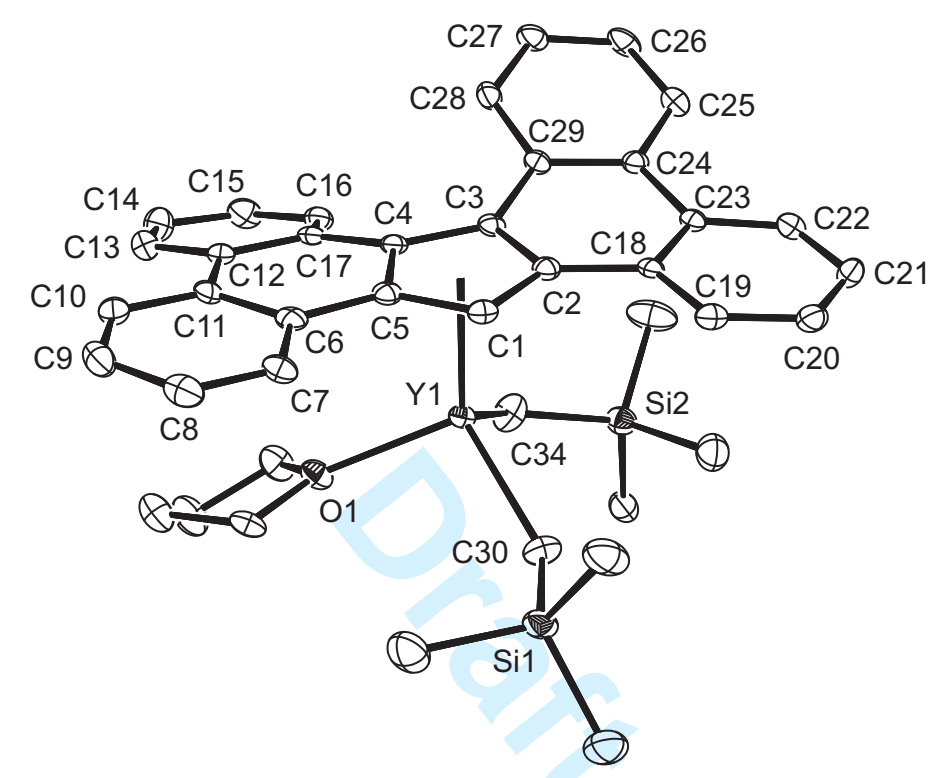

Figure 3. ORTEP ${ }^{19}$ diagram (50\% probability level) for 1 


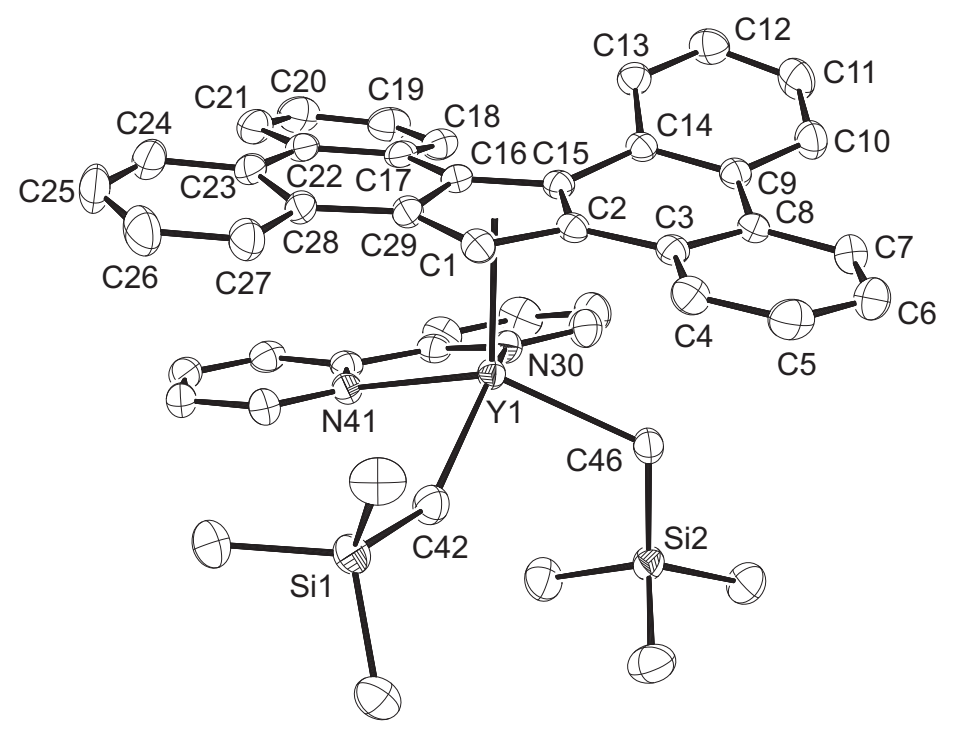

Figure 4 ORTEP $3^{19}$ diagram (40\% probability level) for 2

[Table 2. Selected Bond Distances and Angles for 1 and 2]

The Tbf ligand is clearly distorted in both $\mathbf{1}$ and $\mathbf{2}$ with the two 'back' benzene rings (those furthest from the unsubstituted Cp ring carbon: C12-C17 and C24-C29 in 1; C9-C14 and C17-C22 in 2) of each phenanthrene twisted relative to one another by $38.8^{\circ}$ and $30.9^{\circ}$, respectively. The 'front' benzene rings, in contrast, are only twisted $6.1^{\circ}(\mathbf{1})$ and $3.9^{\circ}(2)$ relative to one another. Thus the twisting occurs between the 'back' benzene rings to minimize steric interactions between the 8 and 8 ' hydrogens. This has been observed before in the free ligand and $\mathrm{Cp}$-alkylated derivatives (range: $16.4-45.8^{\circ}$; median: $37.6^{\circ}$ ) and in lithium salts of the deprotonated Tbf ligand (29.8, $\left.43.7^{\circ}\right) .8 \mathrm{c}, 9,20$ This makes the ligand chiral in the solid state but both enantiomers are present in the unit cells of these complexes by symmetry.

Interestingly, the ${ }^{1} \mathrm{H}$ NMR of 1 in benzene- $d_{6}$ or toluene- $d_{8}$ at room temperature shows only one resonance for the $\mathrm{CH}_{2} \mathrm{SiMe}_{3}$ methylene protons. This is not consistent with the structure observed 
for $\mathbf{1}$ in the solid state because the highest possible symmetry $\left(C_{s}\right)$ still leaves the methylene $\mathrm{H}$ of a given $\mathrm{CH}_{2} \mathrm{SiMe}_{3}$ group inequivalent. The most logical explanation for this is that THF exchange occurs rapidly in solution resulting in effective inversion at the yttrium centre. Indeed, cooling a sample of 1 to $225 \mathrm{~K}$ in toluene- $d_{8}$ results in germinal inequivalence of the two $\mathrm{CH}_{2}$ resonances indicating THF exchange is slow at this temperature (Fig. 5c). The fact that the complex retains $C_{s}$ symmetry at $225 \mathrm{~K}$ also clearly indicates that $\mathrm{Tbf}$ 'wagging' (helical inversion $=$ epimerization) is still rapid at this temperature (Fig. 5a). However on further cooling, this motion slows and by $195 \mathrm{~K}$ becomes slow on the NMR timescale. This can be seen in Fig. 5 for the $\mathrm{CH}_{2}, \mathrm{SiMe}_{3}$ and the 8-aryl protons of the phenanthrene groups. Using the coalescence temperature for the 8 and 8 '-protons or the $\mathrm{SiMe}_{3}$ groups (Fig. 5a and 5b, respectively), a $\Delta \mathrm{G}^{\ddagger}$ for the helical inversion of $\mathbf{1}$ can be calculated to be $38.1 \pm 0.5 \mathrm{~kJ} \mathrm{~mol}^{-1}{ }^{21}$
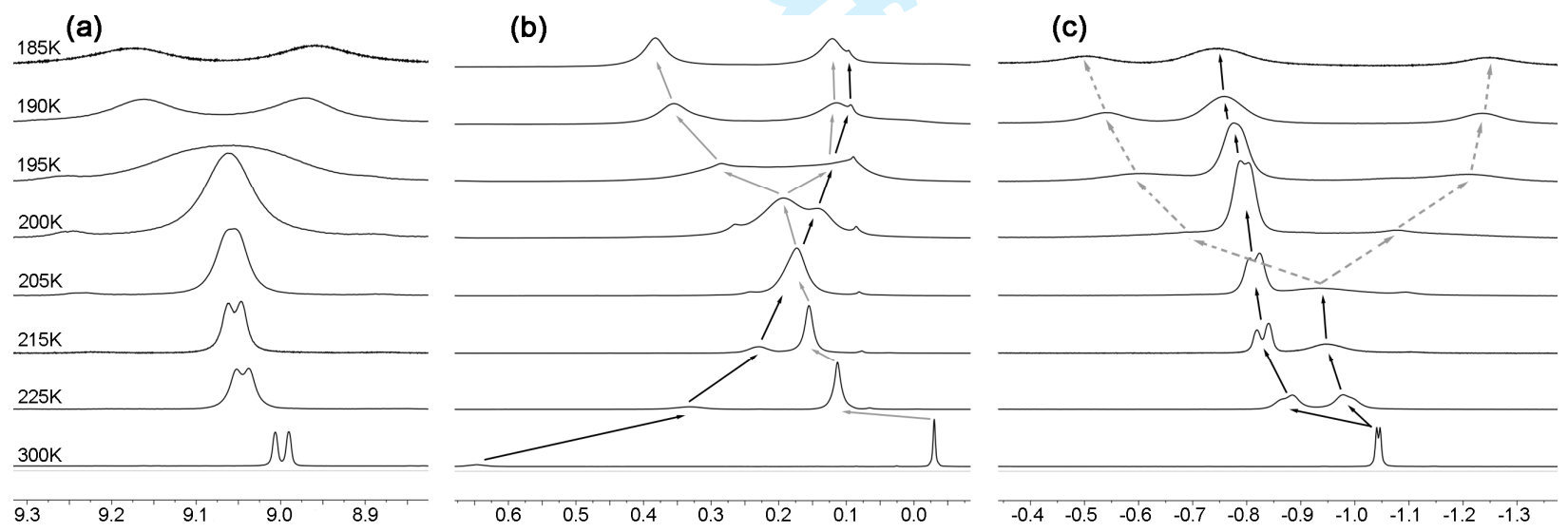

Figure 5 Variable temperature ${ }^{1} \mathrm{H}$ NMR spectra $\left(500 \mathrm{MHz}\right.$, toluene- $\left.d_{8}\right)$ for selected resonances of 1: (a) 8,8'-Tbf; (b) $\alpha-\mathrm{CH}_{2}$ resonances of THF (black arrow), SiMe $e_{3}$ resonances (gray arrows); (c) Y-CH$H_{2}$ resonances (black arrows, onset of geminal inequivalence $\mathrm{CH}_{a} H_{b}$; gray dashed arrows, decoalescence of pairwise related resonances, $\mathrm{CH}_{a}$ and $\mathrm{CH}_{a}{ }^{\prime}$ ). 
Although 1 does not react further with additional Tbf-H, it does react overnight with 1,3$\mathrm{C}_{5} \mathrm{H}_{4}\left(\mathrm{SiMe}_{3}\right)_{2}$ in toluene to afford the mixed ligand complex, [(Tbf) $\left.\left\{\mathrm{C}_{5} \mathrm{H}_{3}\left(\mathrm{SiMe}_{3}\right)_{2}\right\} \mathrm{Y}\left(\mathrm{CH}_{2} \mathrm{SiMe}_{3}\right)(\mathrm{THF})\right]$, 3. This complex shows no tendency to undergo ligand redistribution even when heated at $80{ }^{\circ} \mathrm{C}$ for several days in benzene- $d_{6}$. The reluctance of this compound to undergo ligand exchange no doubt stems from the inability to form bis(Tbf) complexes. However, this complex shows signs of considerable steric congestion in its own right as witnessed by the complete inequivalence of all six methyl groups of the two $\mathrm{SiMe}_{3}$ groups on the 1,3-( $\left.\mathrm{Me}_{3} \mathrm{Si}\right)_{2} \mathrm{Cp}$ ring by ${ }^{1} \mathrm{H}$ and ${ }^{13} \mathrm{C}$ NMR. Free rotation about the Y-Cp centroid would still leave the $\mathrm{SiMe}_{3}$ groups different from each other but the observation of six distinct methyl environments indicates that these groups are locked in place and rotation around the $\mathrm{Si}-\mathrm{Cp}_{\mathrm{C}}$ bond is stopped at room temperature.

The acid-base (protonolysis) reaction of $\mathbf{1}$ with two equivalents of trimethylsilyl acetylene proceeds very rapidly at room temperature with formation of the alkynide complex, $\left[(\mathrm{Tbf}) \mathrm{Y}\left(\mathrm{CCSiMe}_{3}\right)_{2}(\mathrm{THF})\right]_{\mathrm{n}}$, 4. The product precipitates as a toluene-insoluble powder so we assume that this is an oligomer containing alkynide bridging ligands. This complex does however dissolve readily in excess THF- $d_{8}$ and the presence of doublets for both the $\alpha-\left({ }^{1} J_{Y C}=48 \mathrm{~Hz}\right)$ and $\beta$ alkynide $\mathrm{C}\left({ }^{2} J_{Y C}=9 \mathrm{~Hz}\right)$ at 172.46 and $111.95 \mathrm{ppm}$, respectively, in the ${ }^{13} \mathrm{C}\left\{{ }^{1} \mathrm{H}\right\} \mathrm{NMR}$ spectrum, clearly indicates that $\mathbf{4}$ contains terminal alkynides in a monomeric structure.

Interestingly, while attempts to recrystallize $\mathbf{4}$ from hot toluene generally yielded microcrystalline powder, on one occasion, we were able to isolate a small amount of high quality crystals. The X-ray structure of these crystals, however, did not correspond to the bulk product 4 but instead represented a novel trimetallic cluster, 5, containing one Tbf ligand and eight trimethylsilylacetylide anions, Fig. 6. The structure consists of a triangular arrangement of three 
yttrium centres held together by two $\mu^{3}$-face bridging acetylides and three $\mu^{2}$-edge bridging acetylides. The coordination sphere of Y1 further consists of one Tbf ligand showing distinctive ring slippage towards $\eta^{3}$-coordination $\left(\Delta_{\text {slip }}=0.12 \AA\right)$ and a coordinated THF. The remaining coordination sites of the other two metal centres consist of two terminal acetylides (Y2) and one terminal acetylide with one coordinated THF (Y3). Additionally, the two $\mu^{2}$-acetylides bridging between $\mathrm{Y} 1$ and either $\mathrm{Y} 2$ or $\mathrm{Y} 3$ are tilted in such a way that the $\beta$-C of the acetylides are in close contact with Y2 or Y3, so that the alkyne $\pi$-system can interact with the $\mathrm{Y}$ centre, effectively increasing the coordination number from 6 to 7 (Y- $\beta$ C distances: Y2-C36, 2.849(12) $\AA$; Y3-C45, 2.873(12) $\AA$ ). The $\mu^{2}$-acetylide bridging between $Y 2$ and Y3 does not show close contact of the $\pi$ bond with either yttrium centre. Unlike, $\mathbf{1}$ and $\mathbf{2}$, the cluster $\mathbf{5}$ shows significant twisting of the 'front' benzene rings $\left(27.3^{\circ}\right.$ vs. $6.1^{\circ}$ and $3.9^{\circ}$ in $\mathbf{1}$ and $\mathbf{2}$, respectively) relative to one another, indicating that this complex is more crowded at Y1. This is also evident from the long Y1-O(THF) distance of 2.350(8) A compared to the Y3-O(THF) distance of 2.285(7) A. Overall however, the similarity in the $\mathrm{Y}-\mathrm{C}(\mathrm{Tbf})$ bond lengths for $\mathrm{Y} 1$ to those in $\mathbf{1}$ and $\mathbf{2}$ suggest that the $\mathrm{Y} 1$ metal centre in $\mathbf{5}$ is not especially crowded. ${ }^{22}$ 


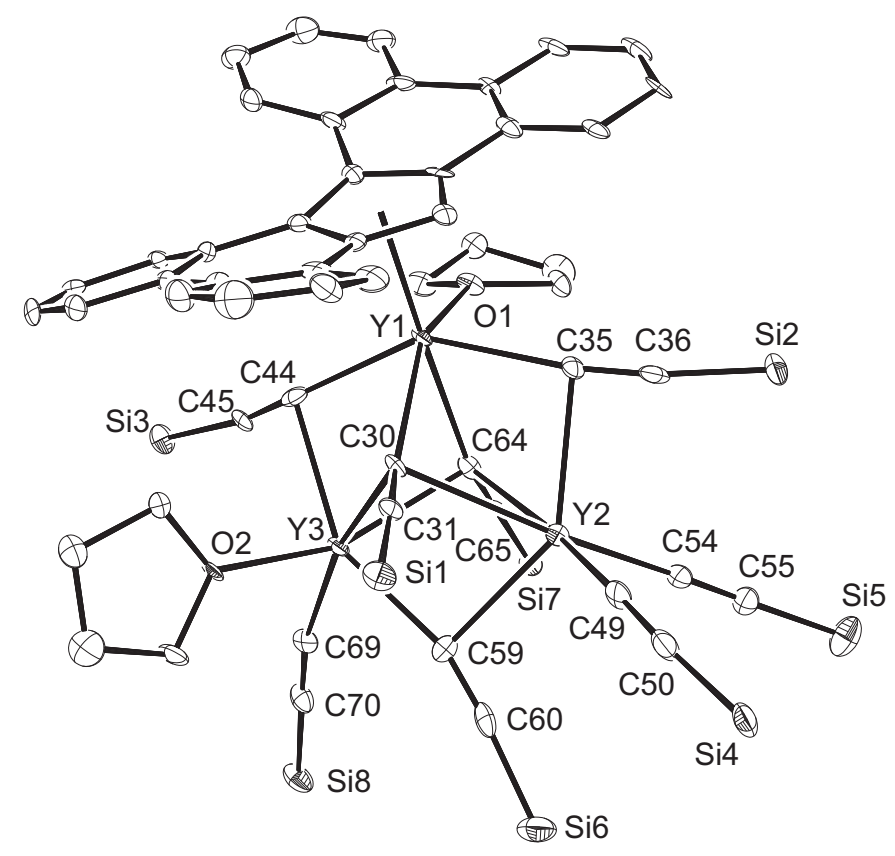

Fig. 6 ORTEP $3^{19}$ diagram (30\% probability level) for 5. Trimethylsilyl methyl groups and trimethylsilylacetylene of solvation removed for clarity.

\section{[Table 3]}

Reaction of 1 with 2 equivalents of trimethylsilylisocyanate $\left(\mathrm{Me}_{3} \mathrm{SiNCO}\right)$ affords the double-insertion product $\left[(\mathrm{Tbf}) \mathrm{Y}\left\{\kappa^{2}-(\mathrm{N}, \mathrm{O})-\mathrm{Me}_{3} \mathrm{SiN}\left(\mathrm{Me}_{3} \mathrm{SiCH}_{2}\right) \mathrm{CO}\right\}_{2}(\mathrm{THF})\right], \mathbf{6}$. The ${ }^{1} \mathrm{H}$ NMR of 6 is consistent with either $C_{s}$ or $C_{2}$ symmetry (the $C_{s}$ isomer is depicted in Scheme 1). Other structures, including those with $\kappa^{1}-\mathrm{O}$ or $\kappa^{1}-\mathrm{N}$ bound ligands are also possible if rapid interconversion between ligand binding modes is occurring at room temperature. Similar insertion reactions with other isocyanates (xylyl, $i$-Pr) and isonitriles also readily occurred at room temperature but the products obtained were impure oily solids in all cases.

The neutral dialkyl 1 does not react with ethylene gas. In order to generate a more reactive alkyl, 1 was treated with an equivalent of trityl tetrakis(pentafluorophenyl)borate. It is presumed 
that this leads to formation of a cationic complex such as 7 (Scheme 1), but the broad, uninformative ${ }^{1} \mathrm{H}$ NMR of the reaction mixture in bromobenzene- $d_{5}$ makes it impossible to establish the exact species present. The ${ }^{19} \mathrm{~F}$ NMR of the $\mathrm{B}\left(\mathrm{C}_{6} \mathrm{~F}_{5}\right)_{4}{ }^{-}$anion showed considerable broadening of the $o$ - and $m$-aryl fluorines which might indicate a significant cation-anion interaction but without further evidence, we cannot say more. ${ }^{23}$ In any case, we decided to see whether the reaction mixture formed on treatment with trityl tetrakis(pentafluorophenyl)borate would polymerize ethylene. Admission of ethylene gas $\left(1\right.$ bar, $\left.20^{\circ} \mathrm{C}\right)$ to the reaction mixture in bromobenzene resulted in formation of polyethylene at a very modest rate $\left(36 \mathrm{~kg} \mathrm{~mol}^{-1} \mathrm{~h}^{-1} \mathrm{bar}^{-1}\right)$. The rate of polymerization observed here is substantially lower than observed in other yttrium alkyl systems. $^{3 \mathrm{a}, 24}$

Interestingly, the reaction mixture formed from $\mathbf{1}$ and trityl tetrakis(pentafluorophenyl)borate in bromobenzene- $d_{6}$ slowly deposited a small amount of yellow plates that on examination by X-ray crystallography turned out to be the $\sigma$-dimer, (Tbf $)_{2}, 8$ (Fig. 7). This dimer has been isolated previously and characterized by X-ray crystallography. ${ }^{8 \mathrm{c}}$ The C-C bond holding the dimer together $(1.614(2) \AA)$ is long indicating considerable steric congestion. As observed in all of the structures above, the 'back' benzene rings of both Tbf units are highly twisted $\left(39.2^{\circ}, 31.2^{\circ}\right)$ while the 'front' benzene rings of one unit are twisted substantially and the other is $\operatorname{not}\left(17.0^{\circ}, 3.2^{\circ}\right)$ 


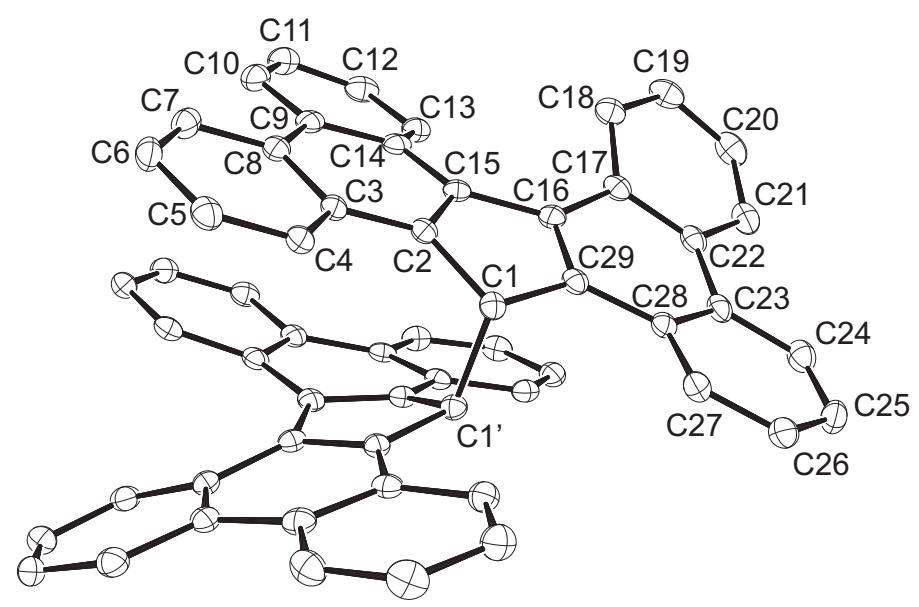

Fig. 7 ORTEP $3{ }^{19}$ diagram (50\% probability level) for $\mathbf{8}$. Benzene- $d_{6}$ of solvation omitted for clarity.

\section{[Table 4]}

4. Concluding remarks The Tbf ligand system allows isolation of thermally stable mono(ligand) dialkyl complexes that do not undergo ligand redistribution reactions. These complexes do undergo acid-base (protonolysis) reactions with acidic hydrocarbons including smaller Cp derivatives and acetylenes. The dialkyl 1 will undergo insertion reactions with small unsaturated substrates such as isocyanates but it will not react directly with ethylene. Treatment of 1 with modest ethylene polymerization catalyst in bromobenzene. The ability to form mono(ligand) complexes that do not undergo extensive coordination polymer formation or ligand redistribution makes the Tbf ligand system a promising scaffold to further explore organolanthanide chemistry. 
Acknowledgment. The support of the Natural Sciences and Engineering Research Council of Canada is gratefully acknowledged.

Materials for Depository. X-ray crystallographic data for 1 (CCDC Ref. No. 1487257), 2 (CCDC Ref. No. 1487258), 5 (CCDC Ref. No. 1487259) and 8 (CCDC Ref. No. 1487260) are available (53 pages). 


\section{References}

1. See for example: (a) Edelmann, F. T.; Lorenz, V. Coord. Chem. Rev. 2016, 306, 346. (b) Ruspic, C.; Moss, J. R.; Schürmann, M.; Harder, S. Angew. Chem., Int. Ed. Engl. 2008, 47, 2121. (c) Gromada, J.; Carpentier, J.-F.; Mortreux, A. Coord. Chem. Rev. 2004, 248, 397. (d) Edelmann, F. T.; Lorenz, V. Coord. Chem. Rev. 2000, 209, 99. (e) Arndt, S., Okuda, J. Chem. Rev. 2002, 102, 1953. (f) Evans, W. J.; Anwander, R.; Doedens, R. J.; Ziller, J. W. Angew. Chem., Int. Ed. Engl. 1994, 33, 1641.

2. The effective size of various substituted $\mathrm{Cp}$ ligands has been reported: Glöckner, A. et al Dalton Trans. 2012, 41, 6614.

3. For some recent papers and reviews of indenyl and fluorenyl complexes of the lanthanides see: (a) Lin, F.; Wang, X.; Pan, Y.; Wang, M.; Liu, B.; Luo, Y.; Cui, D. ACS Catalysis 2016, 6, 176. (b) Deng, M.; Chi, S.; Luo, Y. New J. Chem. 2015, 39, 7575. (c) Perrin, L.; Kirillov, E.; Carpentier, J.-F.; Maron, L. Macromolecules 2010, 43, 6330. (d) Wei, Y.; Yu, Z.; Wang, S.; Zhou, S.; Yang, G.; Zhang, L.; Chen, G.; Qian, H.; Fan, J. J. Organomet. Chem. 2008, 693, 2263. (e) Kirillov, E.; Dash, A. K.; Rodriques, A.-S.; Carpentier, J.-F. Comp. Rendus Chim. 2006, 9, 1151. (b) Aspinall, H. C. Chem. Rev. 2002, 102, 1807.

4. (a) Pammer, F.; Thiel, W. R. Coord. Chem. Rev. 2014, 270-271, 14. (b) Schneider, N.; Schaper, F.; Schmidt, K.; Kirsten, R.; Geyer, A.; Brintzinger, H. H. Organometallics 2000, 19, 3597. (c) Schneider, N.; Prosenc, M. H.; Brintzinger, H. H. J. Organomet. Chem. 1997, 545, 291. (d) Schneider, N.; Huttenloch, M. E.; Stehling, U.; Kirsten, R.; Schaper, F.; Brintzinger, H. H. Organometallics 1997, 16, 3413. (e) Stehling, U. et al Organometallics 1994, 13, 954. (f) Spaleck, W. et al Organometallics 1994, 13, 954. 
5. Simple Hückel calculations indicate that the total charge density in the 5-membered ring of PCp ${ }^{\mathrm{R}}$ ligands is about $93 \%$ of that found in the indenyl analogue: Sun, J. Ph.D. Thesis, University of Victoria, 2007.

6. (a) Sun, J.; Berg, D. J.; Twamley, B. Can. J. Chem. 2013, 91, 1281. (b) Sun, J.; Berg, D. J.; Twamley, B. Organometallics 2008, 27, 683.

7. Berg, D. J.; Sun, J.; Twamley, B. Chem Commun. 2006, 4019.

8. (a) Beckhaus, R.; Schroeder, K.; Schellenberg, J. Syndiotactic Polystyrene 2010, 92. (b) Schroeder, K.; Haase, D.; Saak, W.; Beckhaus, R.; Kretschmer, W. P.; Luetzen, A. Organometallics 2008, 27, 1859. (c) Schroeder, K.; Haase, D.; Saak, W.; Luetzen, A.; Beckhaus, R.; Wickmann, S.; Schellenberg, J. Organometallics 2006, 25, 3824.

9. Frey, O. N.; Stalling, T.; Schlüter, F.; Saak, W.; Schmidtmann, M.; Haase, D.; Beckhaus, R. Dalton Trans. 2016, 45, 1085.

10. (a) Arndt, S.; Zeimentz, P. M.; Spaniol, T. P.; Okuda, J.; Honda, M.; Tatsumi, K. Dalton Trans. 2003, 3622-3627. (b) Barker, G. K.; Lappert, M. F. J. Organomet. Chem. 1974, 76, C45-C46.

11. (a) Hay, A. M.; Hobbs-Dewitt, S.; MacDonald, A. A.; Ramage, R. Synthesis 1999, 1979.

(b) Hay, A. M.; Hobbs-Dewitt, S.; MacDonald, A. A.; Ramage, R. Tet. Lett. 1998, 39, 8721.

12. Hope, H. Prog. Inorg. Chem. 1995, 41, 1.

13. SAINTPlus: v. 6.36a, Data Reduction and Correction Program, Bruker AXS, Madison, WI, 2001.

14. SADABS: v. 2.01, An Empirical Absorption Correction Program, Bruker AXS, Madison, WI, 2001. 
15. SHELXTL: v. 6.10, Structure Determination Software Suite, Sheldrick, G. M., Bruker AXS, Madison, WI, 2001.

16. (a) Nishiura, M.; Baldemus, J.; Shima, T.; Mori, K.; Hou, Z. Chem. Eur. J. 2011, 17, 5033.

(b) Xu, X.; Chen, Y.; Feng, J.; Zou, G.; Sun, J. Organometallics 2010, 29, 549.

17. Jantunen, K. C.; Scott, B. L.; Gordon, J. C.; Kiplinger, J. L. Organometallics 2007, 26, 2777.

18. Shannon, R. D. Acta Cryst. 1976, A32, 751.

19. Farrugia, L. J. ORTEP3 for Windows, J. Appl. Cryst. 1997, 30, 565.

20. (a) Ueda, Y.; Tanigawa, Y.; Kitamura, C.; Ikeda, H.; Yoshimoto, Y.; Tanaka, M.; Mizuno, K.; Kurata, H.; Kawase, T. Chem. Asian J. 2013, 8, 392. (b) Kitamura, C.; Tanigawa, Y.; Kobayashi, T.; Naito, H.; Kurata, H.; Kawase, T. Tetrahedron 2012, 68, 1688. (c) Parsons, S.; Pu, W.; Ramage, R.; Wood, P. A. CSD Private Communication, 2004 (CSD Code: OCAZIC) (d) Brown, A. R.; Irving, S. I.; Ramage, R.; Raphy, G. Tetrahedron 1995, 51, 11815.

21. (a) Calculated using the equal population, two-site exchange equation: $\Delta \mathrm{G}^{\ddagger}=\left(1.912 \times 10^{-}\right.$ $\left.{ }^{2}\right)\left(\mathrm{T}_{\mathrm{c}}\right)\left[9.972+\log \left(\mathrm{T}_{\mathrm{c}} / \delta \mathrm{v}\right)\right]$ in $\mathrm{kJ} \mathrm{mol}^{-1}$ where $\delta \mathrm{v}$ is the separation of the resonances in $\mathrm{Hz}$ at coalescence and $\mathrm{T}_{\mathrm{c}}$ is in $\mathrm{K} .{ }^{19 \mathrm{~b}}$ The error in $\Delta \mathrm{G}^{\ddagger}$ was estimated to be $\pm 0.5 \mathrm{~kJ} \mathrm{~mol}^{-1}$ assuming an error of $\pm 2 \mathrm{~K}$ in $\mathrm{T}_{\mathrm{c}}$ and an error of $5 \mathrm{~Hz}$ in $\delta v$. (b) Sanderson, J. 'Dynamic NMR Spectroscopy', Pergamon, London, 1982.

22. The bond lengths in $\mathbf{5}$ are very similar to those in $\mathbf{2}$ and the shorter three $\mathrm{Y}-\mathrm{C}$ bonds are only marginally longer in $\mathbf{5}$ than in $\mathbf{1}$; the two longer Y-C bonds in $\mathbf{5}$ are however about $0.05 \AA$ longer than those in $\mathbf{1}$. 
23. (a) Laine, A.; Coussens, B. B.; Hirri, J. T.; Berthoud, A.; Friedrichs, N.; Severn, J. R.; Linnolahti, M. Organometallics 2015, 34, 2415. (b) Rocchigiani, L.; Bellachioma, G.; Ciancaleoni, G.; Macchioni, A.; Zuccaccia, D.; Zuccaccia, C. Organometallics 2011, 30, 100. (c) Sciarone, T. J. J.; Nijhuis, C. A.; Meetsma, A.; Hessen, B. Organometallics 2008 , $27,2058$.

24. (a) Nakajima, Y.; Okuda, J. Organometallics 2007, 26, 1270 and references therein. (b) Bambirra, S.; Otten, E.; van Leusen, D.; Meetsma, A.; Hessen, B. Z. Anorg. Allg. Chem. 2006, 632, 1950. (c) Paolucci, G.; Vignola, M.; Zanella, A.; Bertolasi, V.; Polo, E.; Sostero, S. Eur. J. Inorg. Chem. 2006, 4104. (d) Arndt, S.; Spaniol, T. P.; Okuda, J. Angew. Chem., Int. Ed. 2003, 42, 5075. (d) Boisson, C.; Monteil, V.; Ribour, D.; Spitz, R.; Barbotin, F. Macromolec. Chem. Phys. 2003, 204, 1747. (f) Arndt, S.; Beckerle, K.; Hultzsch, K. C.; Sinnema, P.-J.; Voth, P.; Spaniol, T. P.; Okuda, J. J. Molec. Cat. A 2002, $190,215$. 
Table of Contents Graphic

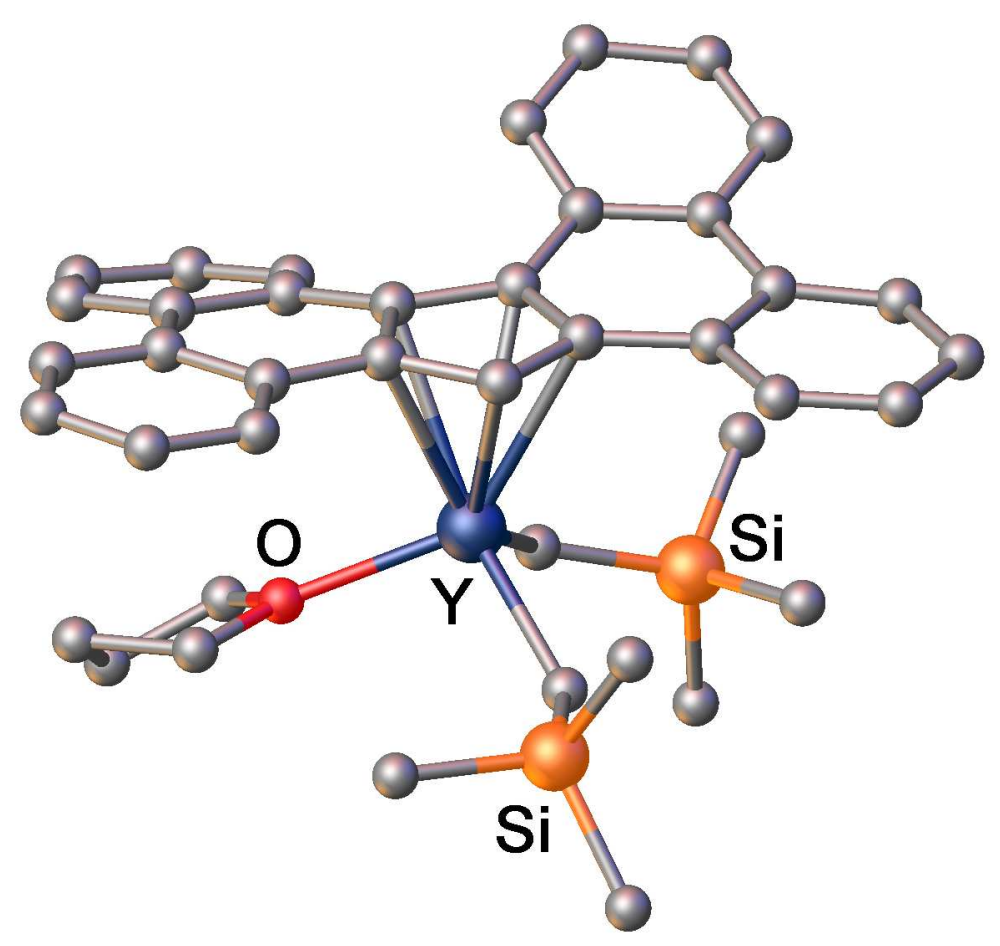


Table 1. Crystallographic data for $\left[\mathrm{Y}(\mathrm{Tbf})\left(\mathrm{CH}_{2} \mathrm{SiMe}_{3}\right)_{2}(\mathrm{THF})\right](\mathbf{1}),\left[\mathrm{Y}(\mathrm{Tbf})\left(\mathrm{CH}_{2} \mathrm{SiMe}_{3}\right)_{2}(\right.$ bipy)] (2), $\left[\mathrm{Y}_{3}(\mathrm{Tbf})\left(\mathrm{CCSiMe}_{3}\right)_{8}(\mathrm{THF})_{2}\right] \cdot\left(0.5 \mathrm{HCCSiMe}_{3}\right)\left(\mathbf{5} \cdot 0.5 \mathrm{HCCSiMe}_{3}\right)$ and $[\mathrm{Tbf}]_{2} \cdot\left(0.5 \mathrm{C}_{6} \mathrm{D}_{6}\right)\left(\mathbf{8} \cdot 0.5 \mathrm{C}_{6} \mathrm{D}_{6}\right)^{\mathrm{a}}$

\begin{tabular}{|c|c|c|c|c|}
\hline & 1 & 2 & 5 & 8 \\
\hline Empirical formula & $\mathrm{C}_{41} \mathrm{H}_{47} \mathrm{OSi}_{2} \mathrm{Y}$ & $\mathrm{C}_{47} \mathrm{H}_{47} \mathrm{~N}_{2} \mathrm{Si}_{2} \mathrm{Y}$ & $\mathrm{C}_{79.5} \mathrm{H}_{110} \mathrm{O}_{2} \mathrm{Si}_{8.5} \mathrm{Y}_{3}$ & $\mathrm{C}_{61} \mathrm{H}_{34} \mathrm{D}_{3}$ \\
\hline Formula weight & 700.9 & 785.0 & 1603.2 & 769.9 \\
\hline Temperature (K) & $86(2)$ & $185(2)$ & $87(2)$ & $87(2)$ \\
\hline Crystal system & Monoclinic & Monoclinic & Monoclinic & Monoclinic \\
\hline Space group & $P 2_{1} / n$ (No. 14$)$ & $P 2_{1} / n$ (No. 14$)$ & $P 2_{1} / c($ No. 14$)$ & $P 2_{1} / n$ (No. 14$)$ \\
\hline$a(\AA)$ & $13.797(3)$ & $11.187(2)$ & $16.685(2)$ & $13.7548(7)$ \\
\hline$b(\AA)$ & $14.840(3)$ & $21.195(3)$ & $14.417(2)$ & $19.4105(10)$ \\
\hline$c(\AA)$ & $18.047(3)$ & $17.318(3)$ & $38.023(5)$ & $15.0190(8)$ \\
\hline$\beta\left({ }^{\circ}\right)$ & $100.77(3)$ & $107.676(15)$ & $98.696(2)$ & $109.039(1)$ \\
\hline Volume $\left(\AA^{3}\right)$ & $3630.0(13)$ & $3912.6(11)$ & $9041.3(19)$ & $3790.5(3)$ \\
\hline$Z$ & 4 & 4 & 4 & 4 \\
\hline Density (calc., g/cm ${ }^{3}$ ) & 1.282 & 1.333 & 1.178 & 1.349 \\
\hline Absorption coeff. $\mu\left(\mathrm{mm}^{-1}\right)$ & 1.703 & 1.588 & 2.061 & 0.076 \\
\hline$F(000)$ & 1472 & 1640 & 3356 & 1612 \\
\hline Crystal size (mm) & $0.42 \times 0.17 \times 0.07$ & $0.34 \times 0.26 \times 0.17$ & $0.29 \times 0.08 \times 0.04$ & $0.20 \times 0.20 \times 0.09$ \\
\hline Crystal color and habit & colourless plate & orange-red block & colourless needle & yellow needle \\
\hline Theta range $\left(\left(^{\circ}\right)\right.$ & 1.71 to 27.61 & 1.56 to 25.25 & 1.51 to 22.50 & 1.74 to 25.25 \\
\hline Reflections collected & 47751 & 58200 & 75831 & 57955 \\
\hline Independent reflections & 8414 & 7080 & 11808 & 6864 \\
\hline Max. and min. transmission & 0.89 and 0.53 & 0.77 and 0.61 & 0.92 and 0.59 & 0.99 and 0.98 \\
\hline Data / restraints / parameters & 8414 / 0 / 412 & $7080 / 0 / 475$ & 11808 / 72 / 861 & 6864 / 0 / 562 \\
\hline Goodness-of-fit on $F^{2}$ & 1.011 & 1.032 & 1.085 & 1.024 \\
\hline
\end{tabular}


Final R indices $[\mathrm{I}>2 \sigma(\mathrm{I})]$

$\mathrm{R}$ (all data)

Largest diff. peak and hole

$$
\mathrm{R} 1=0.082
$$$$
\mathrm{R} 1=0.040
$$

0.48 and $-0.22 \mathrm{e} / \AA^{3}$

${ }^{\text {a }}$ Data was collected on a Bruker / Siemens SMART APEX diffractometer.
$\mathrm{R} 1=0.040, \mathrm{wR} 2=0.087$

$\mathrm{R} 1=0.16$

$\mathrm{R} 1=0.061$

1.68 and $-0.98 \mathrm{e} / \AA^{3}$ 
Table 2. Selected Bond Distances (Å) and Angles (deg) for $\left[(\mathrm{Tbf}) \mathrm{Y}\left(\mathrm{CH}_{2} \mathrm{SiMe}_{3}\right)_{2}(\mathrm{THF})\right]$ (1) and [(Tbf)Y(CH$\left(\mathrm{CH}_{2} \mathrm{SiMe}_{3}\right)_{2}($ bipy $\left.)\right]$ (2). ${ }^{\mathrm{a}}$

\begin{tabular}{llll}
\hline & \multicolumn{2}{c}{ Bond Distances } & \\
& 1 & & \\
$\mathrm{Y}(1)-\mathrm{Cp} 1$ & 2.396 & $\mathrm{Y}(1)-\mathrm{Cp} 1$ & 2.443 \\
$\mathrm{Y}(1)-\mathrm{C}(1)$ & $2.641(3)$ & $\mathrm{Y}(1)-\mathrm{C}(1)$ & $2.640(2)$ \\
$\mathrm{Y}(1)-\mathrm{C}(2)$ & $2.645(3)$ & $\mathrm{Y}(1)-\mathrm{C}(2)$ & $2.689(2)$ \\
$\mathrm{Y}(1)-\mathrm{C}(3)$ & $2.667(3)$ & $\mathrm{Y}(1)-\mathrm{C}(15)$ & $2.804(2)$ \\
$\mathrm{Y}(1)-\mathrm{C}(4)$ & $2.765(3)$ & $\mathrm{Y}(1)-\mathrm{C}(16)$ & $2.780(2)$ \\
$\mathrm{Y}(1)-\mathrm{C}(5)$ & $2.699(3)$ & $\mathrm{Y}(1)-\mathrm{C}(29)$ & $2.721(2)$ \\
$\mathrm{Y}(1)-\mathrm{O}(1)$ & $2.307(2)$ & $\mathrm{Y}(1)-\mathrm{N}(30)$ & $2.519(2)$ \\
$\mathrm{Y}(1)-\mathrm{C}(30)$ & $2.360(3)$ & $\mathrm{Y}(1)-\mathrm{N}(41)$ & $2.469(2)$ \\
$\mathrm{Y}(1)-\mathrm{C}(34)$ & $2.353(3)$ & $\mathrm{Y}(1)-\mathrm{C}(42)$ & $2.396(2)$ \\
& & $\mathrm{Y}(1)-\mathrm{N}(2)$ & $2.423(2)$
\end{tabular}

Bond Angles

$$
\begin{array}{llll}
\mathrm{Cp} 1-\mathrm{Y}(1)-\mathrm{O}(1) & 113.9 & \mathrm{Cp} 1-\mathrm{Y}(1)-\mathrm{N}(30) & 103.6 \\
\mathrm{Cp} 1-\mathrm{Y}(1)-\mathrm{C}(30) & 119.5 & \mathrm{Cp} 1-\mathrm{Y}(1)-\mathrm{N}(41) & 107.5 \\
\mathrm{Cp} 1-\mathrm{Y}(1)-\mathrm{C}(34) & 117.9 & \mathrm{Cp} 1-\mathrm{Y}(1)-\mathrm{C}(42) & 117.3 \\
\mathrm{O}(1)-\mathrm{Y}(1)-\mathrm{C}(30) & 102.76(9) & \mathrm{Cp} 1-\mathrm{Y}(1)-\mathrm{C}(46) & 113.0 \\
\mathrm{O}(1)-\mathrm{Y}(1)-\mathrm{C}(34) & 95.28(10) & \mathrm{N}(30)-\mathrm{Y}(1)-\mathrm{N}(41) & 64.49(6) \\
\mathrm{C}(30)-\mathrm{Y}(1)-\mathrm{C}(34) & 103.93(11) & \mathrm{N}(30)-\mathrm{Y}(1)-\mathrm{C}(42) & 136.11(7) \\
\mathrm{Y}(1)-\mathrm{C}(30)-\mathrm{Si}(1) & 135.4(2) & \mathrm{N}(30)-\mathrm{Y}(1)-\mathrm{C}(46) & 85.69(7) \\
\mathrm{Y}(1)-\mathrm{C}(34)-\mathrm{Si}(2) & 129.3(2) & \mathrm{N}(41)-\mathrm{Y}(1)-\mathrm{C}(42) & 87.48(7) \\
& & \mathrm{N}(41)-\mathrm{Y}(1)-\mathrm{C}(46) & 134.28(7)
\end{array}
$$




$$
\begin{aligned}
& \mathrm{C}(42)-\mathrm{Y}(1)-\mathrm{C}(46) \quad 92.24(8) \\
& \mathrm{Y}(1)-\mathrm{C}(42)-\mathrm{Si}(1) \quad 150.50(12) \\
& Y(1)-C(46)-\operatorname{Si}(2) \quad 115.24(10)
\end{aligned}
$$

${ }^{a}$ estimated standard deviation in parentheses; $\mathrm{Cp}^{1}$ is the centroid of $\mathrm{C}(1)-\mathrm{C}(5)$ for $\mathbf{1}$ and $\mathrm{C}(1), \mathrm{C}(2), \mathrm{C}(15), \mathrm{C}(16), \mathrm{C}(29)$ for 2. 
Table 3. Selected Bond Distances $(\AA)$ and Angles (deg) for $\left[\mathrm{Y}_{3}\left(\mathrm{Tbf}\left(\mathrm{CCSiMe}_{3}\right)_{8}(\mathrm{THF})_{2}\right] \cdot\left(0.5 \mathrm{HCCSiMe}_{3}\right)\left(5 \cdot 0.5 \mathrm{HCCSiMe}_{3}\right){ }^{\mathrm{a}}\right.$

\begin{tabular}{llrl}
\hline & \multicolumn{3}{c}{ Bond Distances } \\
$\mathrm{Y}(1)-\mathrm{Cp} 1$ & 2.426 & $\mathrm{Y}(2)-\mathrm{C}(35)$ & $2.552(12)$ \\
$\mathrm{Y}(1)-\mathrm{C}(1)$ & $2.657(11)$ & $\mathrm{Y}(2)-\mathrm{C}(49)$ & $2.340(14)$ \\
$\mathrm{Y}(1)-\mathrm{C}(2)$ & $2.6791(11)$ & $\mathrm{Y}(2)-\mathrm{C}(54)$ & $2.394(13)$ \\
$\mathrm{Y}(1)-\mathrm{C}(15)$ & $2.773(11)$ & $\mathrm{Y}(2)-\mathrm{C}(59)$ & $2.517(13)$ \\
$\mathrm{Y}(1)-\mathrm{C}(16)$ & $2.721(11)$ & $\mathrm{Y}(2)-\mathrm{C}(64)$ & $2.656(12)$ \\
$\mathrm{Y}(1)-\mathrm{C}(29)$ & $2.610(11)$ & $\mathrm{Y}(3)-\mathrm{O}(2)$ & $2.285(7)$ \\
$\mathrm{Y}(1)-\mathrm{O}(1)$ & $2.350(8)$ & $\mathrm{Y}(3)-\mathrm{C}(30)$ & $2.668(12)$ \\
$\mathrm{Y}(1)-\mathrm{C}(30)$ & $2.500(13)$ & $\mathrm{Y}(3)-\mathrm{C}(44)$ & $2.515(12)$ \\
$\mathrm{Y}(1)-\mathrm{C}(35)$ & $2.463(13)$ & $\mathrm{Y}(3)-\mathrm{C}(59)$ & $2.400(13)$ \\
$\mathrm{Y}(1)-\mathrm{C}(44)$ & $2.530(14)$ & $\mathrm{Y}(3)-\mathrm{C}(64)$ & $2.504(12)$ \\
$\mathrm{Y}(1)-\mathrm{C}(64)$ & $2.563(13)$ & $\mathrm{Y}(3)-\mathrm{C}(69)$ & $2.364(14)$
\end{tabular}

Bond Angles

$\begin{array}{llll}\mathrm{Y}(1)-\mathrm{C}(30)-\mathrm{Y}(3) & 87.3(4) & \mathrm{Y}(1)-\mathrm{C}(64)-\mathrm{Y}(2) & 91.2(4) \\ \mathrm{Y}(1)-\mathrm{C}(35)-\mathrm{Y}(2) & 96.1(4) & \mathrm{Y}(1)-\mathrm{C}(64)-\mathrm{Y}(3) & 89.6(4) \\ \mathrm{Y}(1)-\mathrm{C}(44)-\mathrm{Y}(2) & 90.1(4) & \mathrm{Y}(2)-\mathrm{C}(64)-\mathrm{Y}(3) & 89.6(4) \\ \mathrm{Y}(2)-\mathrm{C}(59)-\mathrm{Y}(3) & 95.5(4) & & \end{array}$

Non-bonding Distances and Angles

$$
\begin{array}{llll}
\mathrm{Y}(1) \cdots \mathrm{Y}(2) & 3.730(2) & \mathrm{Y}(1) \cdots \mathrm{Y}(2) \cdots \mathrm{Y}(3) & 57.95(3) \\
\mathrm{Y}(1) \cdots \mathrm{Y}(3) & 3.570(2) & \mathrm{Y}(2) \cdots \mathrm{Y}(3) \cdots \mathrm{Y}(1) & 62.33(3) \\
\mathrm{Y}(2) \cdots \mathrm{Y}(3) & 3.637(2) & \mathrm{Y}(3) \cdots \mathrm{Y}(1) \cdots \mathrm{Y}(2) & 59.71(3)
\end{array}
$$

${ }^{a}$ estimated standard deviation in parentheses; $\mathrm{Cp}^{1}$ is the centroid of $\mathrm{C}(1,2,15,16,29)$ 
Table 4. Selected Bond Distances $(\AA)$ and Dihedral Angle (deg) for $[\mathrm{Tbf}]_{2}, 8^{\mathrm{a}}$

\begin{tabular}{cccc} 
& \multicolumn{3}{c}{ Bond Distances } \\
$\mathrm{C}(1)-\mathrm{C}\left(1^{\prime}\right)$ & $1.614(2)$ & $\mathrm{C}(2)-\mathrm{C}(15)$ & $1.373(2)$ \\
$\mathrm{C}(1)-\mathrm{C}(2)$ & $1.524(2)$ & $\mathrm{C}(15)-\mathrm{C}(16)$ & $1.483(2)$ \\
$\mathrm{C}(1)-\mathrm{C}(29)$ & $1.506(2)$ & $\mathrm{C}(16)-\mathrm{C}(29)$ & $1.369(2)$ \\
& Dihedral Angle \\
Ar1-Ar2 & 31.2
\end{tabular}

${ }^{a}$ estimated standard deviation in parentheses; Ar1 is the plane defined by $C(9)-C(14)$

and $\mathrm{Ar} 2$ is the plane defined by $\mathrm{C}(17)-\mathrm{C}(22)$ 